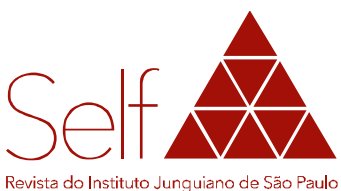

\title{
C. G. Jung on religion
}

\author{
Punita MIRANDA \\ London, United Kingdom.
}

\section{Abstract}

This paper considers Jung's lifelong engagement with the phenomenon of religion. More specifically, it examines the development of his theories in relation to the stages of his life and how religion gradually assumed a definite place in his theory and practice; moving over from psychiatry through psychoanalysis and typology to the theory of archetypes, and finally to the psychology of religious motifs. This study is based on a large literature review of the Jungian works and accounts about the author. From the years spent composing his "The Red Book", Jung struggled to understand the psychological and historical effects of Christianity. The older he got, the more he felt a powerful sense that it was his task to treat the spiritual and religious ills of his patients. His whole oeuvre can be understood as an attempt to grasp the future religious development of the West, in the conviction that religion is necessary for the spiritual evolution of mankind. A strong example of Jung's influence in the second half of the $20^{\text {th }}$ century was the annual Eranos Conferences, which he promoted to discuss innovative ideas about religion. The conferences became one of the most important forums of dissemination of his religious ideas to a broader public. In the

Conflito de interesses:

A autora declara não haver nenhum interesse profissional ou pessoal que possa gerar conflito de interesses em relação a este manuscrito. course of his research he actively cultivated dialogue with theologians and historians of religion, and everything he published had to do with religion to a greater or lesser degree. He even employed religious terms for his therapeutic format, like in the first of the four stages of his analytical process: confession, elucidation, education and transformation.

\section{Descriptors}

Jung, Carl Gustav, 1875-1961, religion, psychology. 


\section{G. Jung e a religião}

\section{Resumo}

Este artigo examina o envolvimento de Jung com o fenômeno da religião durante vários estágios de sua vida e acompanha 0 desenvolvimento correspondente de suas teorias ao longo desses estágios. Demonstra como a religião gradualmente assumiu um lugar definitivo em sua teoria e prática e permeou os temas mais marcantes: a psiquiatria, a psicanálise, a tipologia, a teoria dos arquétipos e, finalmente, a psicologia dos motivos religiosos. As ideias aqui desenvolvidas baseiam-se em uma ampla revisão da literatura sobre a obra junguiana e em uma série de relatos sobre o autor. Desde os anos dedicados à composição de seu "The Red Book", Jung empenhava-se em compreender os efeitos psicológicos e históricos do cristianismo. À medida que amadurecia, mais fortemente sentia que sua tarefa era tratar os males espirituais e religiosos de seus pacientes. Toda a sua obra pode ser entendida como uma tentativa de apreender o futuro desenvolvimento religioso do Ocidente, dada sua convicção de que a religião era necessária para a evolução espiritual da humanidade. Uma poderosa ilustração da influência de Jung sobre a segunda metade do século XX foram as Conferências de Eranos, que ele promovia anualmente para discutir ideias inovadoras sobre religião. As conferências tornaram-se um dos mais importantes fóruns de disseminação de suas ideias religiosas junto ao público mais amplo. Em suas pesquisas, ele ativamente cultivava diálogos com teólogos e historiadores da religião e tudo o que publicava relacionava-se, em alguma medida, com o tema, chegando a empregar termos religiosos para designar a primeira das quatro etapas de seu processo analítico: confissão, elucidação, educação e transformação.

\section{Descritores}

Jung, Carl Gustav, 1875-1961, religião, psicologia. 


\section{G. Jung y la religion}

\section{Resumen}

Este artículo tiene el objetivo de reflexionar sobre las personas Este artigo examina o envolvimento de Jung com o fenômeno da religião durante vários estágios de sua vida e acompanha o desenvolvimento correspondente de suas teorias ao longo desses estágios. Demonstra como a religião gradualmente assumiu um lugar definitivo em sua teoria e prática e permeou os temas mais marcantes: a psiquiatria, a psicanálise, a tipologia, a teoria dos arquétipos e, finalmente, a psicologia dos motivos religiosos. As ideias aqui desenvolvidas baseiam-se em uma ampla revisão da literatura sobre a obra junguiana e em uma série de relatos sobre o autor. Desde os anos dedicados à composição de seu "The Red Book", Jung empenhava-se em compreender os efeitos psicológicos e históricos do cristianismo. À medida que amadurecia, mais fortemente sentia que sua tarefa era tratar os males espirituais e religiosos de seus pacientes. Toda a sua obra pode ser entendida como uma tentativa de apreender o futuro desenvolvimento religioso do Ocidente, dada sua convicção de que a religião era necessária para a evolução espiritual da humanidade. Uma poderosa ilustração da influência de Jung sobre a segunda metade do século XX foram as Conferências de Eranos, que ele promovia anualmente para discutir ideias inovadoras sobre religião. As conferências tornaram-se um dos mais importantes fóruns de disseminação de suas ideias religiosas junto ao público mais amplo. Em suas pesquisas, ele ativamente cultivava diálogos com teólogos e historiadores da religião e tudo o que publicava relacionava-se, em alguma medida, com o tema, chegando a empregar termos religiosos para designar a primeira das quatro etapas de seu processo analítico: confissão, elucidação, educação e transformação.

\section{Descriptores}

Jung, Carl Gustav, 1875-1961, religión, psicología. 


\section{Introduction}

I do not expect any believing Christian to pursue these thoughts of mine any further, for they will probably seem to him absurd. I am not, however, addressing myself to the happy possessors of faith, but for whom the light has gone out, the mystery has faded, and God is dead. For most of them there is no going back, and one does not know either whether going back is always the better way. To gain understanding of religious matters, probably all that is left us today is the psychological approach (Jung, 1938/1969, CW11, p. 89, §148).

The rise of psychology came about in the atmosphere of late $19^{\text {th }}$ century Germanic Europe as a reaction to rationalism, materialism and the Nietzschean (1882/2001) idea of the death of God, proclaimed in 1882, with the publication of "The Gay Science" (Brooke, 1991; Nagy, 1991). Between the 1870s and 1930s the major disciplinary and theoretical forms of modern psychology and psychotherapy were established (Shamdasani, 2003). As a central feature of modernity, psychology has arisen in direct proportion to the decline of the power of religion and, as historian of psychology and Jungian scholar, Shamdasani puts it, it represents "the most decisive act in the completion of the scientific revolution" (Shamdasani, 2003, p. 4) Peter Homans (1930-2009) argued that the emergence of psychology "is but one more victory in the chronic warfare between theology and science' and that there is something, in a substitutive sense, about psychology, as it could be seen as modern man's 'invisible religion'" (Homans, 1995, pp. 8-9). From this perspective religion is an age-old historical force and psychology a modern response to it.

The significance of the Swiss psychiatrist Carl Gustav Jung (18751961) for the $20^{\text {th }}$ century lies in the power his ideas and his personality, resulting in the organisation of a highly influential movement around his theories, known as analytical psychology. Jung was the inheritor of many trends of $19^{\text {th }}$ century thoughts and his psychology responded to scientific and philosophical problems of the turn of the century. In philosophy he found historical analogues for many of his intuitions, which helped lay the idealistic foundations of his psychology. Some of these influential intellectual encounters were with the works of Immanuel Kant (1724-1804), Arthur Schopenhaver (1788-1860), and Eduard von Hartmann (1842-1906) (Jung, 1951/1980, CW9-I). In Kant's writing Jung found that "there is no knowledge of what is beyond our experience" and this philosophical orientation was to be stressed by Jung's emphasis on the authority of individual experience, which in his case was of a religious nature (Nagy, 1991). 
This belief in the primacy of inner experience and of inner feeling coincided with the radically new way of approaching theology inaugurated by the Protestant theologian Friedrich Schleiermacher (1768-1834) who considered the source of religion to be an immediate feeling or consciousness, precursor to rational awareness. In approaching theology from the viewpoint of experience Schleiermacher sought to free religious belief and practice from metaphysical argument and ground it in human experience, arguing that "religion ought not to be reduced to science, metaphysics, or morality" (Proudfoot, 1985, p. xiii). This focus on the importance of describing religious experience from the subject's perspective was formative in shaping subsequent studies of religious phenomena. Jung himself was influenced by two wellknown proponents of Schleiermacher's new approach: the American philosopher and psychologist William James (1842-1910) and the German Lutheran theologian Rudolf Otto (1869-1937), whose concept of the numinous was to become a corner stone of Jung's psychology.

Perhaps the close connection between the life and work of an individual is nowhere more clearly portrayed than in the case of Jung. One can fully appreciate his endeavours as a scientific pioneer and investigator through his interest in and involvement with the 'irrational' aspects of experience, from the position both as a private individual and as professional psychiatrist in the public eye (Shelburne, 1988).

The role of Jung's personal religious experiences was key to the formation of his ideas. He felt compelled to search and offer something with which to combat both scientific and religious doubt. These experiences were assimilated into his theoretical thinking and his concepts are attempts at formulating "a new scientific psychology based upon immediate experience" (Jacobi, 1962, p. vii.), while aiming to resolve major debates in philosophy, sociology, biology, anthropology and comparative religion (Shamdasani, 2003).

His lifelong preoccupation with the phenomenon of religion and its relation to the mental suffering of mankind led the mature Jung to attempt to understand the psychological and historical effects of Christianity and grapple with the problem of the presence of evil in a world created by a loving, compassionate God. Filtering a wide variety of disciplines Eastern and Western through his personality, Jung claimed to have objectively approached and annexed to science a realm of the human soul intermediate between psychology and religion (Ellenberger, 1970). He was "the most prominent modern psychologist to affirm religious values" and indeed one field with which his works have been most engaged is that of religious studies (Shamdasani, 1998, pp. 3-4). 
In "The Brill Dictionary of Religion" (von Stuckrad, 2007), Jung's name is discussed in several contexts: in volume II he is mentioned under "esotericism": Jung a scholar of, (as the alternative study to the institutionalised scriptural religions of Europe) was part of a countermovement against the 'disenchantment of the world' and Eranos Conferences were a circle of researches and creators of myth, of a revival enlightenment. In volume III under "myth": a contribution to the symbolical theory to study of myth; "new age": his spiritualised psychology had an impact on various social and cultural changes that characterised modern society in the last decades of the $20^{\text {th }}$ century; "psyche": his analytical psychology is concerned with healing and freighted with religious features especially with parallels between psychotherapy and Christianity; "psychoanalysis": Jung with his idea of archetypes and collective unconscious, added a religious strata to the psychoanalytical movement; and in volume IV under "science fiction": he interpreted the unidentified flying object (UFO) as a modern religion of redemption.

In the course of his research he actively cultivated dialogue with theologians and historians of religion, including the Dominican priest Father Victor White (1902-1960), the Jewish philosopher Martin Buber (1878-1965), and the Protestant theologian Paul Tillich (18861965). As the Professor of German studies and Jung scholar Christine Maillard emphasises, the stature that Jung accorded to religious people makes his oeuvre one of the major works of psychology of religion in the $20^{\text {th }}$ century (Maillard, 2006).

A strong example of Jung's influence in the second half of the $20^{\text {th }}$ century was his promotion of one of the most dynamic and innovative discourses on religion, the annual Eranos Conferences near Ascona in Switzerland, dedicated to the study of the interplay between psychology, philosophy, religion and spirituality. Eranos had the configuration of a 'research laboratory' and Jung was a dominating figure during the first phase of its existence.

How, though, are we to understand the origins, formation, and context of Jung's unique ideas on religion? The lens through which we have chosen to examine the development of the theories of Jung's psychology of religion are connected to the stages of his life and their relation to his thought, which rests upon the foundation of two solid pillars: his personal experiences and clinical observations.

\section{Early personal experiences}

Nobody could rob me of the conviction that it was enjoined upon me to do what God wanted and not what I wanted. That gave me the strength to go my own way. Often I had the feeling that in decisive matters I was no 
longer among men, but was alone with God (Jung, 1961/1995, p. 65).

Jung was led to a confrontation with religious questions by several different routes, having had a Protestant minister of the Swiss Reformed Church as a father, two uncles on the father's side as clergymen and six on the mother's side as theologians he heard many religious conversations, theological discussions and sermons (Jung, 1961/1995, p. 58). In a letter to Henry Corbin on 4 May 1953 Jung wrote:

Schleiermacher really is one of my spiritual ancestors. He even baptized my grandfather - born a Catholic [...] the vast, esoteric, and individual spirit of Schleiermacher was a part of the intellectual atmosphere of my father's family. I never studied him, but unconsciously he was for me a spiritus rector (Jung, 1953/1976, p. 115).

It is hardly surprising, then, that the overtly religious familial background would have an influence on his life. This being said, it was not so much the traditional religious input that instigated Jung, for this would soon enough prove to be empty ritual and dogma; but more the fact that his childhood was filled with bizarre dreams, visions and religious dilemmas, including a view of God as both good and terrible, which gave him a powerful and disturbing sense of the reality of evil. It can be noted in his dreams of the man-eating phallus between the ages of three and four, which he perceived as a 'subterranean god' (Jung, 1961/1995, p. 27); a vision of God (age 12) sitting on his golden heavenly throne defecating on the roof of Basel Cathedral and shattering it (Jung, 1961/1995, p. 56); his disappointment with his father's lack of understanding about the contradiction of the Trinity (age 15) while giving him the instructions for confirmation and his dull experience in receiving the Communion, which proved to be a total loss: "this is not religion at all, it is an absence of God, the church is not a place of life, but death" (Jung, 1961/1995, p. 73); the confirmation of his feelings regarding evil: "someone takes the devil seriously" (Jung, 1961/1995, p. 77), when he read Goethe's Faust when he was 16 years old.

The disappointment with external, exoteric Christianity - Jung rejected the traditional and conventional religion of his father and community: "insofar as they all represented the Christian religion, I was an outsider" (Jung, 1961/1995, p. 74) - and the emotional tone of his direct inner experiences induced in him an "almost unendurable loneliness". Jung recounts in his biography:

[...] thus the pattern of my relationship with the world was already prefigured: today as then I am solitary, because I know things and must hint at things which other people 
do not know, and usually do not even want to know (Jung, 1961/1995, p. 58).

This was to burden him with the task of seeking a way to understand and overcome not only his personal, but also the general contemporary malaise of spiritual alienation (Shamdasani, 2009). This way, of course, was psychiatry, which would become for Jung the path where "the collision of nature and spirit became a reality" (Jung, 1961/1995, p. 130).

\section{Early professional years - psychiatric development}

Knowledge of the subjective contents of consciousness means very little, for it tells us next to nothing about the real, subterranean life of the psyche [...] medical knowledge of this kind is merely information about an illness, but not knowledge of the soul that is ill (Jung, 1952/1967, CW5, p. xxvi) (Emphasis added).

As described in the previous section, religion was a subject of personal interest to Jung, though it was only gradually that it assumed a definite place in his theory and practice. His interest steadily moved over the years from psychiatry through psychoanalysis and typology to the theory of archetypes, and finally to the psychology of religious motifs (Jung, 1961/1985, CW4). We will briefly address these developments, as they are key for an understanding of how his psychology contributed to a religious perspective in human life.

Jung worked as a psychiatrist at the University of Zürich Burghölzli Psychiatric Hospital from 1900 to 1909 where he brought about a transformation in psychiatry with his application on word association test, which eventually won him an international reputation. At that time his interest in religious phenomena was brief and overlapped with cases of psychopathological disturbances, for instance, schizophrenia, manic disorders, hallucinations and visions. He was convinced that delusions, hallucinations and some occult phenomena had religious-tones but was not to venture further in this context until much later in his career. For example, since 1902, when he published his doctoral thesis "On the psychology and psychopathology of so-called occult phenomena" it already contained intimations of his ideas in germinal form: the superior receptivity of the unconscious over the conscious mind, that psychological disturbances have teleological significance and that the unconscious spontaneously produces mythological material (Heisig, 1979).

It is important to mention that during the years of his experimental research, Jung personally met several international cutting-edge 
thinkers, including the American philosopher and psychologist William James (1842-1910), the Swiss philosopher and medical doctor Théodore Flournoy (1854-1920), and, of course, the Austrian neurologist Sigmund Freud (1856-1939). A brief outline of the work of these great men seems relevant as their paramount repercussion contributed to the development of Jung's intrapsychic basis for psychology.

William James was extremely influential not only in religious but also in psychological studies and psychic research. He drew from a range of academic disciplines and his background as a psychologist provided him with insights into religion that had no affiliation with any particular religious community. His books "The principles of psychology" (1890/1918), "The varieties of religious experience: A study in human nature" (1902/2004), and "Pragmatism and four essays from the meaning of truth" (1907/1970) provided not only an interface between psychology and religion but also the important distinction between inward versus outward orientation of psychic energy. In the "The varieties of religious experience: A study in human nature", James (1902/2004) claimed that the unconscious was the doorway to religious awakening which was to become a useful model for Jung. In a letter to Kurt Wolff on 17 September 1958, Jung wrote: "aside from Théodore Flournoy, James was the only outstanding mind with whom I could conduct an uncomplicated conversation. I therefore honour his memory and have always remembered the example he set me" (Shamdasani, 2003, p. 58).

A lifelong friend of William James and strongly influenced by his pragmatism, Théodore Flournoy held the first chair of psychology at the University of Geneva in 1892. It was the first time that psychology was seen as science as opposed to philosophy (Shamdasani, 2003). Both Flournoy and James were interested in a psychology that would include the transcendent dimensions of the personality and were leading investigators of the subliminal psyche. Flournoy (1900) was one of the first to record the psychologization of multiple personalities in his book "From India to the Planet Mars". At that time the psychologists' encounter with séances marked an important step in the study of the subliminal personality: the reality of god and spirits was then seen as a subjective phenomenon within man, i.e., an intrapsychic phenomenon and this shift paved the way for the psychologization of 'God-within the psyche'. This would later become Jung's working hypothesis of an autonomous entity within the psyche that men have always identified with metaphysical beings. 
${ }^{1}$ Editors' note:

The original work

"Wandlungen und

Symbole der Libido",

that materialized

strongly Jung's

departure from Freud's

ideas, was published in

two parts (1911 and

1912) and translated

into English in 1916 as

"Psychology of the

unconscious". In 1952

Jung released a new

definitive edition of the

same work under the

name of "Symbole der

Wandlung", translated

in 1956 into English,

now called "Symbols of transformation" and for

Portuguese as

"Símbolos da

transformac,ão".
As is well known, Freud's interest was in sexual repression of the libido, but unlike Jung, he had no experience with psychotic patients. Nevertheless, between the years 1906 and 1913 the two men had seven years of rich collaboration and exchange. Despite the admiration he felt for the Austrian pioneer, Jung gradually elaborated and elucidated a position diametrically opposed to that of Freud. In his paper "The significance of the father in the destiny of the individual" (Jung, 1949/1985, CW4) Jung took a decisive step, expanding Freud's importance of the father-child relationship into a man-God relationship; thereby 'heretically' turning the secular sacred. Here, for the first time, we see Jung's tentative steps into the psychology of religion.

Over the next few years, Jung grew more and more critical of Freud's materialistically reductive sexual theory and began a serious study of mythology. In the midst of his studies he came upon the fantasy material of a young American, Miss Miller, which had been published by Théodore Flournoy (1906). Out of the study of her religious fantasies came Jung's book "Wandlungen und Symbole der Libido" (1911-1912), translated as "Symbols of transformation" (1952/1967, CW5)' a work that marked a return to the roots of his cultural and religious preoccupations (Shamdasani, 2009). Jung enlarged on Freud's notions of libido and incest and provided a new understanding of religion. He tried to analyse the psychological dynamics behind religious phenomena, using comparative, mythological and etymological material rather than simply dismissing them for their apparent 'unreality'. The mythological images and their psychological contents were initially described by Jung as 'dominants', 'gods', or the ruling powers of the psyche. Jung chronologically called them 'primordial images' in 1911, 'dominants' in 1917 and 'archetypes' in 1919 (Shamdasani, 2003, p. 37).

Soon after he came to realize that the sum of these images constituted a second psychic system of a collective, universal, and impersonal nature, and, contrary to Freud's theory, this psychic system did not develop individually but was inherited: "'The creative substratum is everywhere this same human psyche and this same human brain, which with relatively minor variations, functions everywhere in the same way" (Jung, 1952/1967, CW5, p. xxix).

As early as 1913 Jung recognised that the differences between Freud and himself were primarily differences in religious attitude (Nagy, 1991). As Victor White said: "It seems that, whereas for Freud religion is a symptom of psychological disease, for Jung the absence of religion is at the root of all adult psychological disease" (White, 1952, p. 47). "Symbols of transformation" (1952/1967, CW5) was a ground-breaking work, laying the foundations for Jung's later 
theoretical constructions and contained in seed form the concepts of his theory of the archetypes and the collective unconscious. Given the depth of its subject matter and the ground that was broken, perhaps it is no surprise that its publication also severed the relationship between these two colossal figures of psychology.

With hindsight Jung elaborated in 1929 the differences between his views and Freud's:

Because of [my differences] I am accused of mysticism. I do not, however, hold myself responsible for the fact that man has always and everywhere, spontaneously developed a religious function, and that the human psyche from time immemorial has been shot through with religious feeling and ideas [...] This father complex, defended with such stubbornness and oversensitivity, is a religious function misunderstood, a piece of mysticism expressed in terms of biological and family relationships. As for Freud's concept of the 'superego', it is a furtive attempt to smuggle the time-honoured image of Jehovah in the dress of psychological theory. For my part, I prefer to call things by the names under which they have always been known. (Jung, 1929/1985, CW4, p. 339, § $781)$.

From this quote it can be clearly understood why Jung and Freud parted ways; even though the symptoms they observed in their patients were similar, their ways of approaching and dealing with them led to very different conclusions; for Jung, libido was rooted in archetypes, not in the drive forces of the sexual libido (Nagy, 1991). Even though he retained Freud's word 'libido', Jung elaborated it as a mobilising energy, and went as far to speculate that: (a) god represented a certain form of energy that has been projected from its unconscious origin onto a metaphysical reality; (b) monotheism is due to the libido as a common shared source; (c) religious and magic rites are means of mobilising libido for definite purposes. Jung's intention was not divinise the libido, but rather to psychologise that which man project as divine (Ellenberger, 1970; Heisig, 1979).

\section{Mature personal experiences - "The Red Book"}

This severing wasn't without damage and freedom came with a price. After the final break with Freud in 1913, the psychoanalytic community parted from Jung, and he also stepped down as editor of Jahrbuch für psychologische und psychopathologische Forschungen, the first scientific publication of psychoanalytic research, published by Freud and Bleuler (1909/1913) (Jung, $1961 / 1995$, p. 191). The following year, in 1914, Jung resigned from 
both the presidency of the International Psychoanalytic Association and from his position as Privatdozent at the University of Zürich (Jung, 1961/1995, pp. 218-225). His professional crisis triggered a period of disorientation and his propensity for personal experience of a religious kind reasserted itself (Homans, 1995). From October 1913 to July 1914 he had a series of twelve separate apocalyptic visions that threatened him with the fear of becoming psychotic. Several years later he expressed these fears to his friend, the historian of religion, Mircea Eliade (1907-1986):

As a psychiatrist I became worried, wondering if I was not on the way to "doing a schizophrenia", as we said in the language of those days [...] I was just preparing a lecture on schizophrenia to be delivered at a congress in Aberdeen, and I kept saying to myself: "I'll be speaking of myself! Very likely I'll go mad after reading out this paper" [...] On July 31 $1^{\text {st }}$, immediately after my lecture, I learned from the newspapers that war had broken out. Finally I understood. And when I disembarked in Holland on the next day; nobody was happier than I. Now I was sure that no schizophrenia was threatening me. I understood that my dreams and my visions came to me from the subsoil of the collective unconscious. What remained for me to do now was to deepen and validate this discovery. And this is what I have been trying to do for forty years (McGuire \& Hull, 1977, pp. 233-234).

As Jung recounts, even though the experience wasn't without its risks, he realised that what his fantasies had been depicting was not happening to him alone but to the whole of Europe. This fact convinced him that his fear of going mad was misplaced and brought a confirmation that he needed to deepen the understanding of his fantasies on both subjective and collective levels. From that time on he gave permission to "the soul to speak". In a relevant example of a dialogue Jung had with his soul on January 8, 1922 his soul informed him:

Relations do not let themselves be replaced by the deepest knowledge. Moreover a religion does not consist only in knowledge, but at its visible level in a new ordering of human affairs. Therefore expect no further knowledge from me. You know everything that is to be known about the manifested revelation, but you do not yet live everything that is to be lived at this time.

Jung's 'I' replied: "I can fully understand and accept this. However, it is dark to me, how the knowledge could be transformed into life. You must teach me this." 
His soul said: "There is not much to say about this. It is not as rational as you are inclined to think. The way is symbolic (Jung, 2009, p. 211).

Between 1913 and 1929 he composed a literary work of psychology - "The Red Book", a spiritual narrative with the overall theme of encounters and dialogues with a series of subliminal figures which led to the rebirth of a new image of God in his soul, a new worldview in the form of a psychological and theological cosmology. Shamdasani in the introduction of "The Red Book" explains that Jung attempted to formulate things in terms of revelation, that his prewar visions that led to the composition of 'Liber Novus' were prophetic. "The Red Book: Liber Novus" represents a private opus that ran parallel to and alongside his public scholarly opus; while the latter was nourished by and drew from the former, they remained distinct (Shamdasani, 2009).

Jung's 'journey into the unconscious' became the great mainspring from which his psychological system originated. The collective unconscious and the archetypes that had been known to him from his work with patients and from literature he now experienced personally; in the 'unconscious psyche' laid a source of knowledge, higher wisdom and guidance (Jung, 2009; Nagy, 1991). From this self-experiment he acquired his first notions of anima, the self, individuation and mandala symbolism. He later systematised this experimental process as a therapeutic method for his patients, called 'active imagination', a tool used to explore this new field of experience. It can take the form of dialogue, drawing, painting with the unconscious (Hannah, 2001; Hull, 1971; Jung, 1956/1970 CW14; Jung, 1958/1981, CW8; Jung, 2009; von Franz, 1998). Barbara Hannah, one of Jung's earliest collaborators, gives credit to Jung for discovering but not inventing the idea of active imagination; she pointed out that it was an age-old 'form of meditation which man has used to learn to know his God or gods' (Hannah, 2001).

Over the course of these 16 years that he worked on "The Red Book", Jung continued to expand and to develop his selfexperimentation while attempting to formulate an intellectual conception of it in his written papers. This was a very creative period and he drew inspiration to shape his theories from various sources, East and West. In 1929 Jung stopped working in "The Red Book" when the Sinologist Richard Wilhelm sent him a Taoist alchemical treatise "The secret of the golden flower" (Wilhelm, 1929/2010) and asked him to write a commentary on it.

Impressed by the parallelism between the images of the text and his mandalas he began to publicly work towards building a bridge of psychological understanding between East and West at the same time he privately began a cross-cultural study on medieval 
alchemy. Several of Jung's paintings in "The Red Book" are inspired by Eastern books and philosophy; during this period he turned to Eastern religion for support and insight (Coward, 1985; Jung, 1929/1983, CW13).

After 1930 Jung's work could be considered as an extended amplification of the contents of in his "The Red Book" and some of the statements closely correspond to positions that Jung would later articulate in his "Collected Works", they "each mutually explicate the other". His "The Red Book" is now historically placed in a hermeneutic relationship with Jung's subsequent writings (Shamdasani, 2009).

A Western source that pointed Jung in a new direction was "The idea of the holy: An inquiry into the non-rational factor in the idea of the divine and its relation to the rational" (1917), written by the German theologian Rudolf Otto. Jung recognized in Otto's book a suitable description of his physical and emotional responses in the face of the mysterium tremendum and fascinans: "[...] it lies rather, in a peculiar 'moment' of consciousness, to wit, the stupor before something 'wholly other', whether such an other be named 'spirit', daemon, or deva, or be left without any name [...]" (Otto, 1917/1959, p. 41).

It is Otto's (1917/1959) definition of religion as numinous feeling as "dynamic agency or effect not caused by an arbitrary act of will" that Jung adopts as his own (Jung, 1938/1969, CW11; Nagy, 1991). He psychologically understood the significance of what Otto was describing because of the overpowering nature of the visions that he was being confronted with and confirmed that a numinous quality accompanied the manifestation of an archetype:

I must stress one aspect of the archetypes which will be obvious to anybody who has practical experience of these matters. That is, the archetypes have, when they appear, a distinctly numinous character which can only be described as 'spiritual' if 'magical' is too strong a word. Consequently this phenomenon is of the utmost significance for the psychology of religion (Jung, 1947/1981, CW8, p. 205, § 405).

He further expanded the numinous to include "fateful transformations [...] that can take the form of conversions, illuminations, emotional shocks, blows of fate, religious or mystical experiences or their equivalents" (Jung, 1942/1969, CW11, pp. 183184, $\S 274)$, placing the archetypes as the origin of religious experience. Thereafter, Jung made use of the numinous to refer to a variety of psychological phenomena that had mostly to do with archetypal manifestations, referring to it as a 'numinous quality' of 
the archetype and this has been assimilated into the Jungian lexicon.

Shamdasani points out that from 1923 onwards Jung's work on the psychology of religion and the relation of religion to psychology became more and more pronounced. Interested in the psychology of religious experience, because of what he learned through his selfinvestigation, he attempted to develop a psychology of the 'religious-making process'. Shamdasani makes a clear point when he elucidates that rather than proclaiming a new prophetic revelation, Jung's

[...] task was to depict the translation and transposition of the numinous experience of individuals into symbols, and eventually into the dogmas and creeds of organized religions, and, finally, to study the psychological function of such symbols. He was aware that for such a psychology of the religion-making process to succeed, it was essential that analytical psychology, while providing an affirmation of the religious attitude, did not succumb to becoming a creed (Shamdasani, 2009, p. 219).

This concern will be addressed in the last part of the essay. After Jung's 'confrontation with the unconscious' waned, the 'confrontation with the world' began (Shamdasani, 2009). He started giving private seminars that he conducted from 1925 until 1941, but the next important stage of his intellectual development was the Eranos Conferences at Ascona, Switzerland.

\section{Eranos: A platform for new ideas}

I can formulate my thoughts only as they break out of me. It is like a geyser. Those who come after me will have to put them in order (Jaffé, 1983, p. 8).

Emerging just before World War II and going through and beyond the Cold War era, the Eranos Conferences can be understood as the product of a historical period which responded to pre- and postwar anxiety, running counter to the domineering claims of materialism and positivism. In spite of the tremendous impact this innovative discourse on religion had on culture in general - even as an instigator of the New-Age movement, much of its legacy is now found outside the academy, on the margins of departments of religious studies.

Eranos (from the Greek 'shared feast') was the name chosen by Rudolf Otto for annual meetings at the home of the Dutch born Frau Olga Fröbe-Kapteyn. The first meeting took place in 1933 and the gatherings she organized were theosophically oriented at first, but they gradually developed into a broad humanistic and scientific 
discussion center on a very high level. Dutch professor of Western Esotericism Wouter Hanegraaff suggests that the first period of these gatherings might well be called 'the Jung Era' (Hanegraaff, 2012) and Swedish professor of Religious Studies Olav Hammer points out that the Eranos Conferences might have been the most important forum of dissemination of Jung's religious ideas to a broader public (Hammer, 2006).

The Conferences attracted a series of religious intellectuals from all over the world, including the presence of the renowned pioneer historian of Jewish kabbalah Gershom Scholem (1897-1982), the Islamicist Henry Corbin (1903-1978), and the scholar of religion Mircea Eliade among others. They lectured on a variety of topics concerning religion, myth, symbolism and their relevance to the history of modern culture. Professor of the history of the study of religion, Steven Wasserstrom argues that these scholars brought about a new kind of intellectual vitalism, where they transcended disciplinary limitations in order to articulate a modern study of religion, favouring symbols and myths with a focus on the centrality of mystical experiences (Wasserstrom, 1999).

On the one hand these religious thinkers had a common platform to launch their unique views, on the other hand, each held a different approach to myth, history and theories of religion. For example, in a letter to Eliade, Jung reproached him for using the term 'archetype' without differentiating his own usage from Jung's. He used the word to describe the historical development of ideas in human culture and this was a distinctly different meaning from what Jung had in mind (Jung, 1955/1976, p. 212; Nagy, 1991).

This essay shall now explore how these meetings offered Jung an opportunity to explore and exchange some of his psychological discoveries, especially the myth-making capacity of humanity, archetypes and the collective unconscious, which form the foundation of his psychology of religion.

Jung attended the Eranos Conferences from 1933 to 1951 almost uninterruptedly, apart from a few occasions when illness prevented him. It was during these years that a lot of what he published in the Eranos Jahrbuch later became integrated into the editions of several of his "Collected Works". In 1934, for instance, he delivered the lecture Archetypes of the collective unconscious, which was to become volume 9, Part I, of his "Collected Works".

It is not possible to understand Jung's thesis on religion without a grasp of his theory of archetype. As mentioned above, his initial conceptions began to develop through the period of his pre-war visions, which he then elaborated in the 1920s and 1930s, with them undergoing alteration over the course of his life; consequently, a brief, general definition is necessary. 
First of all, Nagy points out how Jung's metaphysics is well expressed in his theory of the archetype. The philosophical antecedents of Jung's theory of archetypes are to be found first in Plato's doctrine of transcendent causes, and secondly more directly in Schopenhaver's dynamic theory of the Will. In the speculations of his late years Jung extended his theory of non-material, archetypal causes beyond the sphere of individual psychic life to the realm of conjunction with the material world, in his theory of synchronicity (Nagy, 1991).

Jung believed that all humanity shared a psychic force that bears the power of the sacred because of a predisposition towards religious experience, like Eliade, he called this homo religiosus and define that as "the man who takes into account and carefully observes certain factors which influence him and his general condition" (Jung, 1938/1969, CW11, pp. 9-10, §11). He insisted that this is not something invented but a spontaneous experience that leaves a cultural imprint on our imagination. Jung's idea of the archetype is that of a riverbed, a blueprint, or even a structure like that of the skeleton, which is part of the human constitution, the individual feature being the only variant (Jung, 1936/1964, CW10, 1945/1983, CW13).

Jung argued that any particular historical manifestation, for instance Christ or Buddha, never exhausts the possibility of expression that lies behind the manifestation. For him there is an archetypal potential for the experience of a God-image and this potential has been filled in by all the religious symbols of mankind (Corbett, 2007; Dourley, 1981). Jung's attitude involves a dialectic between the individual and its universal basis: this innate capacity to produce a 'private, subjective' image, prior to formal religious education will be superimposed and developed by the religious practices and doctrines of the culture we are born into (Corbett, 2007).

For him it was possible to appreciate the Christian myth more fully while at the same time freeing the Christian mind from possible dangerous claims of uniqueness, by withholding judgment about the truth of religious belief, and paying attention to the psychological value of religious symbolism (Dourley, 1984). Jungian analyst Marilyn Nagy and Professor of Modern German Paul Bishop both suggest that Jung's theory of archetype is an attempt to work out a 'universal grammar' of the mind, the psychic structures that inform our mental and emotional development, and psychology is a good instrument for understanding and interpreting all forms of religion (Bishop, 2002; Nagy, 1991). 


\section{Defining religion}

One of the consequences of the interdisciplinary discussions with historians and theologians at Eranos was that Jung was stimulated and challenged to present working psychological definitions of religion, however his definition is a wide one. Less concerned in defining religion and more frequently referring to religion as 'therapeutic systems', Jung left aside all questions of metaphysics and ontology. He points out:

My attitude to all religions is therefore a positive one. In their symbolism I recognise those figures which I have met with in dreams and fantasies of my patients [...] Ceremonial ritual, initiation rites, and ascetic practices, in all their forms and variations, interest me profoundly as so many techniques for bringing about a proper relation to these forces [of psychic life] (Jung, 1929/1985, CW4, p. $337, \S 777)$.

From this perspective one can see how Jung sees religion as psychic facts and how his attention tends to focus on its archetypal basis and psychological meaning. Moreover, he was struck by the contrasting methods of observation employed by Eastern and Western religions and even though attracted by similarities, for him, the two were radically different and this is clarified by the subtitle of one of his major works on religion: "Psychology and religion: West and East" (Collected Works, vol. 11). This book represents Jung's touchstone of his approach to the psychology of religion in a more systematic view.

The essays that form "Part One" are especially significant because they are full of Christian symbolism and his psychological interpretation of religious phenomena. Particularly significant are the famous Terry Lectures on "Religion in the light of science and philosophy" that Jung delivered at Yale University in 1937 (Collected Works, vol. 11).

In these lectures Jung formally engaged with Otto's concept of the numinous, stating that "religion is a careful and scrupulous observation of what Rudolf Otto aptly termed the numinosum" and in the passage below it is possible to see how he expanded on Otto's definition in a general way, explaining that religion is also an attitude that involves:

[...] a careful consideration and observation of certain dynamic factors that are conceived as 'powers': spirits, daemons, gods, laws, ideas, ideals, or whatever name man has given to such factors in his world as he has found powerful, dangerous, or helpful enough to be taken into careful consideration, or grand, beautiful, ad meaningful 
enough to be devoutly worshipped and loved (Jung, 1939/1969, CW11, pp. 7-8, § 8).

Jung is convinced that religious experience outweighs theological concept and clarifies that when he employs the term 'religion', he does not mean a creed, as creeds are codified and dogmatised forms of original religious experience, in which the original religious experience has become systematised as a collective truth within a certain tradition.

While remaining sceptical with regard to established religion, Jung never ceased to be deeply concerned with religion, it was for him, a function of the psyche deeply impressed upon us as a result of the capacity that human beings have of formulating God-images (Jung, 1939/1969, CW11, p. 43, §75; Lammers, 1994).

After the 1940s, in his thinking and writing Jung focused almost exclusively on religious matters, especially Christian themes. In his essays on "A psychological approach to the dogma of the Trinity" (Collected Works, vol. 11) he explores the main topics of Christ as archetype, summarizing it as "Christ himself is the perfect symbol of the hidden immortal within the mortal man" (Jung, 1950/1980, CW9I, p. 121, § 218), postulating that the "outward historical Christ could potentially wake up the Christ within" (Jung, 1958/1973, CW18, p. 725, § 1638). Jung also proposed with his hypothesis of the 'Quaternity' (as opposed to the Trinity), a new, radically psychological explanation for the 'missing feminine' and the genesis and meaning of evil in the world.

Jung's essay "Transformation symbolism in the mass" in "Psychology and religion: West and East" (Collected Works, vol. 11), his continuing work on alchemy and Gnosticism can be seen to be increasingly informing his writings and underpinning many of his arguments (Stein, 1999). Philosopher of Religion James Heisig speculated that the idea that gave rise to Jung's 'Quaternity' model might have derived from his Gnostic writing "Seven sermons to the dead" (1916/1967) where Jung addressed four principal 'gods': Helios (Father), Eros (Son), Life (Spirit), and Devil. Jung was also aware that the Gnostics attempted to introduce the feminine into the Trinity (Heisig, 1979).

In 1944 Jung published "Psychology and alchemy", a book that grew out of two lectures given at Eranos in 1935/1936. Heisig pointed out that there is "no better outline of Jung's views on religion in the whole of his published and unpublished works, than his 'Introduction to the religious and psychological problems of alchemy'" (Heisig, 1979). In it Jung presents his psychological viewpoint saying that the "reality of religion" is grounded in a certain "faculty of relationship to God". According to him psychology comes to aid the encounter between man and its unconscious archetypal contents: 
The fact that is that with the knowledge and actual experience of these inner images a way is opened for reason and feeling to gain access to those other images which the teaching of religion offers to mankind. Psychology, thus does the opposite of what it is accused of: it provides possible approaches to a better understanding of these things, it open people's eyes to the real meaning of dogmas, and far from destroying it, it throws open an empty house to new inhabitants (Jung, 1944/1980, CW12, p. 15, § 17).

Jung thought that the value of his psychology of religion was its capacity to 'revivify religious traditions', especially Christianity. A large portion of his later work was dedicated to his early preoccupations with the problem of evil and its origin, expressed mainly in his correspondence with the English Dominican priest Victor White who helped him refine his interpretation of Catholicism for several years before he entered the public arena with his published writings, in particular, "Aion: Researches into the phenomenology of the Self" (Collected Works, vol. 9-II) and "Answer to Job" (Collected Works, vol. 11).

During the 15 years of their collaboration, Jung and White had an ambitious bridge-building project, whose goal was to develop strong theoretical and practical connections between the church's doctrines and Jungian psychology. White was impressively well informed and spoke the language of Thomistic theology as skillfully and coherently as Jung spoke that of analytical psychology. Jung's texts often cite Biblical authors, church fathers and heretics, Gnostic and alchemical texts, mythology and comparative religion. Few readers were as competent to assess the use Jung made of such diverse sources as White was (Lammers, 1994; Lammers \& Cunningham, 2007).

Jung's "Aion: Researches into the phenomenology of the Self" (Jung, CW 9-II) throws light on the myth of Christianity, which has been the dominating Western myth for 2000 years. Jung saw in the $20^{\text {th }}$ century the end of a world and the passage to a new stage of religious evolution, which he called a "new aeon" (Maillard, 2006, p. 652). Jung clarifies:

I had attempted to explain how the appearance of Christ coincided with the beginning of a new aeon, the age of the Fishes. A synchronicity exists between the life of Christ and the objective astrological event, the entrance of the Spring Equinox into the sign of Pisces. Christ therefore the 'Fish' (just as Hammurabi [the founder of Babylonian civilisation] before him was the 'Ram'), and comes forth as the ruler of the new aeon (Jung, 1961/1995, p. 248). 
"Aion: Researches into the phenomenology of the Self" is Jung's first effort to deal with the psychological meaning of Christ as a divine figure. He claimed that there is a contradiction in the Christian tradition of evil as privatio boni (absence of good) and the fact of the devil's existence prior to man's creation and stressed that both the Christian archetype and the archetype of God lack a dark side: "The Christ-symbol lacks wholeness in the modern sense, since it does not include the dark side of things but specifically excludes it in the form of a Luciferian opponent" (Jung, 1951/1978, CW9-II, p. $41, \S 74)$.

The following year Jung produced "Answer to Job" (Collected Works, vol. 11), which is a direct continuation of "Aion: Researches into the phenomenology of the Self" in a far more personal and intense work that shows Jung's inner struggle with God, exploring the crucial question: 'whence evil'? In his old age, Jung remarked that he wished he could rewrite all of his books except this one. With this book he was completely satisfied (von Franz, 1998).

Commenting on the biblical "Book of Job", Jung discusses the ambivalent deity and the inadequacy of the one-sidedness traditional Western image of God. The book contains his debate with the Judeo-Christian conception of God, going backwards to the days of creation and forwards to the vision of the Apocalypse (Bishop, 2002). It was a highly controversial and provocative book that has attracted criticism at several levels and cost his friendship with White, his most important theological conversation partner (Lammers, 1994; Lammers \& Cunningham, 2007).

Although Jung did not develop his views on the psychology of religion beyond these two books, Jung scholar Ann Lammers suggests that there is such a sense of urgency in his writings - from the beginning of World War I, when he felt that his prewar visions were prophetic, until the end of his life - that it seems as if he felt under a pressing personal obligation to bring the fruits of his psychological discoveries to assist a world at peril (Heisig, 1979; Lammers, 1994).

Jung rounded out his ideas after "Aion: Researches into the phenomenology of the Self" and "Answer to Job" in his last major work, "Mysterium Coniunctionis" (Collected Works, vol. 14) in which he established his psychology upon the historical foundations of alchemy. He explains:

Thus my task was finished, my work done, and now it can stand. The moment I touched bottom, I reached the bounds of scientific understanding, the transcendental, the nature of archetype per se, concerning which no further scientific statements can be made (Jung, 1961/1995, p. 248). 
Jung's legacy: Psychological insights regarding religion

My endeavours in psychology have been essentially pioneer work, leaving me neither time nor opportunity to present them systematically. (Jacobi, 1962, p. xi).

Professor of Psychology Roger Brooke points out Jung's pioneering works ran mostly in parallel with the growth phenomenology's in the first half of the $20^{\text {th }}$ century, though he never made use of its methodological guidelines in a systematic and disciplined way. He believes that Jung's method is better described as a combination of phenomenological and empirical research that makes use of introspective and descriptive techniques (Brooke, 1991). Jung indeed insisted on making his method scientific but had little time to elaborate his methodology because of the continuous revision of his theories, the amplification of earlier ideas at the same time as new developments became the focus of his pioneer work. This being the case, there is not a single approach that accurately reflects the nature of his method.

Heisig pointed out that the defining characteristic of Jung's psychology of religion is his method of 'objective amplification', which involves three stages: (a) the gathering of primary data, (b) the search for parallels, analogies an comparative material among the documents of history, and (c) the interpretation of former in the light of the latter (Heisig, 1979).

From years of observing and investigating dreams, fantasies, visions, and psychotic delusions, Jung was more concerned with the psychological origins and effects of religion. His search was for a psychological method with which both to understand and treat the diseases of the human soul. Shamdasani (2009) argues that Jung was convinced that the 'enlightened' era of reason and skepticism inaugurated by the French Revolution had repressed religion and irrationalism. This, in turn, had serious consequences, eventually leading to the outbreak of irrationalism represented by the World Wars (Shamdasani, 2009, p. 210).

In Jung's views the profound changes brought about by the wars and by a civilisation dominated by materialism instigated two unconscious phenomena in which the masses: (a) either project the neglected archetypes onto persons and nations, thus transforming them into dangerous enemies; (b) or they become a modern variant of the fanatical religions: "our fearsome gods have only changed their names: they now rhyme with ism" (Jung, 1999, CW7; Wulff, 1990). In one of Jung's later essays "The Undiscovered Self" (1957), he declares: "The State takes the place of God; that is why, seen from this angle, the socialist dictatorships are religions and State slavery is a form of worship" (Jung, 1957/1964, CW10, p. 259, § $511)$. It was thus a historical necessity to acknowledge the irrational 
as a psychological factor and it became the task of psychology, not only, to understand, but also, to foster the development of a new consciousness for new times.

\section{Conclusions}

Among all my patients in the second half of life - that is to say, over thirty-five - there has not been one whose problem in the last resort was not that of finding a religious outlook on life. It is safe to say that every one of them fell ill because he had lost what the living religions of every age have given to their followers, and none of them has been really healed who did not regain his religious outlook. (Jung, 1932/1969, CW1 1, p. 334, § 509).

Throughout his life Jung strove to develop a psychology that respected individual differences at the same time as scientifically taking into consideration general properties of psychic processes. For him the solutions to collective problems were best approached through the psychological transformation of the individual (Shamdasani, 2003).

Partly because of his religious background, and partly because he believed that the psycho-dynamics he had uncovered underlie religious formulations, Jung liked to describe this process in religious terms (MacKenna, 2008). Everything he published had to do with religion to a greater or lesser degree, to the extent that he even employed religious terms for his therapeutic format, like the first of the four stages of his analytical process: confession, elucidation, education and transformation (Jung, 1929/1981, CW16, p. 55, § 122).

Although Jung never considered himself a traditional Christian, the symbols of God and Christ, the contrasting forces of good and evil, and the fundamental significance of religious symbolism run like leitmotifs through most of his works. He had an ambivalent relationship to Christianity, simultaneously criticizing and valuing it he challenged the Christian standpoint but at the same time argued that religion served to put us in touch with the otherwise inaccessible unconscious mind (Heisig, 1979). With his engagement with Eastern religion, moreover, Jung's psychology not only challenged the prevailing Christian monopoly in the West, but also offered a spiritual dimension far beyond anything then (or currently) available through any single religious tradition (Dourley, 1984).

Since the years spent composing "The Red Book", Jung struggled to understand the psychological and historical effects of Christianity and the older he got the more he felt a powerful sense that it was his task to treat the spiritual and religious ills of his patients. 
His whole oeuvre can be understood as an attempt to grasp the future religious development of the West, in the conviction that religion was necessary for the spiritual evolution of mankind (Shamdasani, 2009, p. 207). Since time immemorial religions had been systems for healing psychic illness and Jung noticed that with the decline of religious life, the neuroses had grown more frequent due to society's spiritual stagnation, psychic sterility and lack of meaning.

In "The Red Book" we find the first intimations of his new-found faith in the relevance of his depth psychology: "Our age is seeking a new spring of life. I found one and drank of it and the water tasted good" (Shamdasani, 2009, p. 210).

Three decades later, in "Psychology and religion: West and East" he expressed the vital importance of his therapy of the soul for the modern man confronted with this inner emptiness:

[...] that is why we psychotherapists must occupy ourselves with problems which, strictly speaking, belong to the theologian. But we cannot leave these questions for theology to answer; challenged by the urgent psychic needs of our patients, we are directly confronted with them every day. (Jung, 1932/1969, CW11, p. 344, § 532).

From a Jungian perspective, man's innate capacity for accessing the divine outside the confines of creed and dogma grants it spiritual autonomy, liberating the imagination from the outward image. The psychological approach embraces the religious in such a way that its spiritual value is neither damaged nor reduced. On the contrary, the spiritual is confirmed and amplified through the psychological (Stein, [2018]).

By thus approaching religion through psychology, by turning one's attention to the inner world, Jung believed that the individual regains access to the source of psychic life, marking the beginning of the cure (Jung, 1954/1969). Ultimately, then, for him psychological illness was, at root, religious in nature and depth psychology a Heilsweg in both senses of the word: a way of healing and a way of salvation (Jacobi, 1962).

Author's note: I am citing Jung's "Memories, dreams, reflections" (1961) aware of Shamadasani's (1995) article "Memories, dreams, omissions", where he clarifies that this book should be read as a 'biography' instead of an 'autobiography'. 


\section{References}

Bishop, P. (Ed.) (2002). Jung's answer to job: A commentary. London: Brunner- Routledge.

Brooke, R. (1991). Jung and phenomenology. London: Routledge.

Corbett, L. (2007). Psyche and the sacred. New Orleans: Spring Journal.

Coward, H. (1985). Jung and the Eastern thought. Albany, NY: State University of New York Press.

Dourley, J. P. (1981). The psyche as sacrament: A comparative study of C. G. Jung and Paul Tillich. Toronto: Inner City Books.

Dourley, J. P. (1984). The illness that we are. Toronto: Inner City Books.

Ellenberger, H. F. (1970). The discovery of the unconscious: The history of dynamic psychiatry. New York: Basic Books.

Flournoy, T. (1900). From India to the planet Mars: A study of a case of somnambulism with glossolalia. New York; London: Harper \& Brothers Publishers.

Flournoy, T. (1906). Quelques faits d'imagination créatrice subconsciente. Archives de psychologie, (5), 36-51.

Freud, S., \& Bleuler, E. (Eds). (1913). Jahrbuch für psychologische und psychopathologische Forschungen. (Original work published 1909).

Hammer, O. (2006). Jungism. In W. J. Hanegraaff (Ed.), Dictionary of gnosis and Western esotericism (pp. 653-655). Leiden: Brill.

Hanegraaff, W. J. (2012). Esotericism and the academy: Rejected knowledge in Western culture. Cambridge: Cambridge University Press.

Hannah, B. (2001). Encounters with the Soul: Active Imagination as developed by C.G Jung. Brooklyn, NY: Chiron Publications.

Heisig, J. W. (1979). Imago Dei: A study of C. G. Jung's psychology of religion. Lewisburg: Bucknell University Press.

Homans, P. (1995). Jung in context: Modernity and the making of a psychology. Chicago: University of Chicago Press.

Hull, R. F. C. (1971). Bibliographical Notes on Active Imagination in the Works of C.G. Jung. Junguiana Spring, 115-120.

Jacobi, J. (1962). The psychology of C.G. Jung. London: Routledge \& Kegan Paul.

Jaffé, A. (1983). The myth of meaning. Zürich: Daimon Verlag.

James, W. (1918). The principles of psychology (Vols. 2). London: Macmillan. (Original work published 1890).

James, W. (1970). Pragmatism and four essays from the meaning of truth. Cleveland: Meridian. (Original work published 1907). 
James, W. (2004). The varieties of religious experience: A study in human nature, introduction and notes by Wayne Proudfoot. New York: Barnes \& Noble Books. (Original work published 1902).

Jung, C. G. (1964). Wotan. In Civilization in transition (R. F. C. Hull, trans., The Collected Works, Vol. 10). London: Routledge \& Kegan Paul. (Original work published 1936).

Jung, C. G. (1964). The undiscovered Self. In Civilization in transition (R. F. C. Hull, trans., The Collected Works, Vol. 10). London: Routledge \& Kegan Paul. (Original work published 1957).

Jung, C. G. (1967). VIl sermones ad mortuos the seven sermons to the dead written by Basilides in Alexandria, the city where the East toucheth the West. London: Watkins Publishing. (Original work published 1916).

Jung, C. G. (1967). Symbols of transformation (R. F. C. Hull, trans., The Collected Works, Vol. 5). Princeton, NJ: Princeton University Press. (Original work published 1952).

Jung, C. G. (1969). Psychotherapists or the clergy. In Psychology and religion: West and East (R. F. C. Hull, trans., The Collected Works, Vol. 11). London: Routledge \& Kegan Paul. (Original work published 1932)

Jung, C. G. (1969). The Terry lectures of 1937. In Psychology and religion: West and East (R. F. C. Hull, trans., The Collected Works, Vol. 11). London: Routledge \& Kegan Paul. (Original work published 1938).

Jung, C. G. (1969). A psychological approach to the dogma of the Trinity. In Psychology and religion: West and East (R. F. C. Hull, trans., The Collected Works, Vol. 11). London: Routledge \& Kegan Paul. (Original work published 1942)

Jung, C. G. (1970). Mysterium coniunctionis (R. F. C. Hull, trans., The Collected Works, Vol. 14). Princeton, NJ: Princeton University Press. (Original work published 1956).

Jung, C. G. (1973). Jung and the religious belief. In The symbolic life (R. F. C. Hull, trans., The Collected Works, Vol. 18). Princeton, NJ: Princeton University Princeton, NJ: Princeton University Press. (Original work published 1958).

Jung, C. G. (1976). Letter to Henry Corbin on 4 May 1953. In C. G. Jung letters: 1951-1961. (G. Adler and A. Jaffé, eds., R. F. C. Hull, trans., Vol. 2). London: Routledge \& Kegan Paul. (Original work published 1953).

Jung, C. G. (1976). Letter to Mircea Eliade on 19 January 1955. In C. G. Jung letters: 1951-1961. (G. Adler and A. Jaffé, eds., R. F. C. Hull, trans., Vol. 2). London: Routledge \& Kegan Paul. (Original work published 1955). 
Jung, C. G. (1978). Aion: Researches into the phenomenology of the self (R. F. C. Hull, trans., 2nd ed., The Collected Works, Vol. 9-2). Princeton, NJ: Princeton University Press. (Original work published 1951).

Jung, C. G. (1980). Psychology and alchemy (R. F. C. Hull, trans., The Collected Works, Vol. 12). Princeton, NJ: Princeton University Press. (Original work published 1944).

Jung, C. G. (1980). The psychology of rebirth. In The archetypes and the collective unconscious (R. F. C. Hull, trans., The Collected Works, Vol. 9-1). Princeton, NJ: Princeton University Press. (Original work published 1950).

Jung, C. G. (1980). The psychology of the child archetype. In The archetypes and the collective unconscious (R. F. C. Hull, trans., The Collected Works, Vol. 9-1). Princeton, NJ: Princeton University Press. (Original work published 1951).

Jung, C. G. (1981). On the nature of the psyche. In: The structure and dynamics of the psyche (R. F. C. Hull, trad., The Collected Works, Vol. 8). Princeton, NJ: Princeton University Press. (Original work published 1947).

Jung, C. G. (1981). The transcendent function. In The structure and dynamics of the psyche (R. F. C. Hull, trad., The Collected Works, Vol. 8). Princeton, NJ: Princeton University Press. (Original work published 1958).

Jung, C. G. (1981). Problems of modern psychotherapy. In The practice of psychotherapy (R. F. C. Hull, trans., The Collected Works, Vol. 16). London: Routledge \& Kegan Paul. (Original work published 1929).

Jung, C. G. (1983). Comentary on "The secret of the Golden Flower". In Alchemical studies. (R. F. C. Hull, trans., The Collected Works, Vol. 13). Princeton, NJ: Princeton University Press. (Original work published 1929).

Jung, C. G. (1983). The philosophical tree. In Alchemical studies. (R. F. C. Hull, trans., The Collected Works, Vol. 13). Princeton, NJ: Princeton University Press. (Original work published 1945).

Jung, C. G. (1985). The significance of the father in the destiny of the individual. In: Freud and psychoanalysis (R. F. C. Hull, trad., The Collected Works, Vol. 4). Princeton, NJ: Princeton University Press. (Original work published 1909/1949).

Jung, C. G. (1985). Freud and Jung: Contrasts. In Freud and psychoanalysis (R. F. C. Hull, trad., The Collected Works, Vol. 4). Princeton, NJ: Princeton University Press. (Original work published 1929).

Jung, C. G. (1985). Editorial note. In Freud and psychoanalysis (R. F. C. Hull, trad., The Collected Works, Vol. 4, pp. 1-5). Princeton, NJ: Princeton University Press. (Original work published 1961). 
Jung, C. G. (1995). Memories, dreams, reflections (A. Jaffé, ed., R. Winston and C. Winston, trans.). London: Fontana Press. (Original work published 1961).

Jung, C. G. (1999). Two essays on analytical psychology (R. F. C. Hull, trad., The Collected Works, Vol. 7). London: Routledge \& Kegan Paul.

Jung, C. G. (2009). The Red Book: Liber novus (S. Shamdasani, org.). London \& New York: W.W. Norton \& Company.

Lammers, A. C. (1994). In God's shadow: The collaboration of Victor White and C. G. Jung. New York: Paulist Press.

Lammers, A. C., \& Cunningham, A. (Eds.). (2007). The Jung: White Letters. London: Routledge.

MacKenna, C. (2008). Jung's White raven, review essay of the JungWhite letters. British Journal of Psychotherapy, 24 (3), 365-379.

Maillard, C. (2006). Jung, Carl Gustav. In W. J. Hanegraaff (Ed.), Dictionary of gnosis and Western esotericism (pp. 648-653). Leiden: Brill.

McGuire, W., \& Hull, R. F. C. (Eds). (1977). C.G. Jung peaking: Interviews and encounters (Bollingen Series). Princeton, NJ: Princeton University Press.

Nagy, M. (1991). Philosophical issues in the psychology of C.G. Jung. New York: State of University Press.

Nietzsche, F. (2001). Cambridge: Cambridge University Press. (Original work published 1882).

Otto, R. (1959). The idea of the holy: An inquiry into the non-rational factor in the idea of the divine and its relation to the rational (J. W. Harvey, trad.). Harmondsworth: Penguin Books. (Original work published 1917).

Proudfoot, W. (1985). Religious experience. Berkeley: University of California Press.

Shamdasani, S. (1998). Cult fictions: C.G. Jung and the founding of analytical psychology. London: Routledge.

Shamdasani, S. (2003). Jung and the making of modern psychotherapy, the dream of a science. Cambridge: Cambridge University Press.

Shamdasani, S. (2009). Introduction. In C. G. Jung, The Red Book: Liber Novus. London \& New York: W.W. Norton \& Company.

Shelburne, W. A. (1988). Mythos and logos in the thought of Carl Jung: The theory of the collective unconscious in scientific perspective. Albany: University of New York Press.

Stein, M. (1999). Encountering Jung on Christianity. Princeton, NJ: Princeton University Press. 
Stein, M. ([2018]). On the importance of numinous experience in the alchemy of individuation. Available from: http://murraystein.com/articles.shtml.

von Franz, M.-L. (1998). C.G. Jung: His myth in our time. Toronto: Inner City Book.

von Stuckrad, K. (Ed.). (2007). The brill dictionary of religion. Leiden: Brill. (4 Vols.).

Wasserstrom, S. M. (1999). Religion after religion: Gershom Scholem, Mircea Eliade, and Henry Corbin at Eranos. Princeton, NY: Princeton University Press.

White, V. (1952). God and the unconscious. London: Harvill Press.

Wilhelm, R. (2010) The secret of the golden flower, commentary by C.G. Jung. San Diego: The Book Tree. (Original work published 1929).

Wulff, M. (1990). Psychology of religion: Classic and contemporary views. New York: John Wiley.

Mini-curriculum: Punita Miranda - Graduated in Clinical Psychology from UniCeub (Brasilia/DF); master's degree in research from the Center for History of Hermetic Philosophy and Related Currents (Amsterdan/ Netherlands), with a master's thesis entitled "O 'Livro Vermelho' de Jung e a história da psiquiatria no século XIX". Completed the Leadership Traing Program, conducted by the Jungian analist Marion Woodman in Canada and England. Candidate for the diploma of Jungian analist at the GAP Institute (London). London/ United Kingdom. Email: punita.miranda@gmail.com 